\title{
A NEW SPECIES OF OPITHES FROM MEXICO WITH A KEY TO THE SPECIES (COLEOPTERA: STAPHYLINIDAE)*
}

\author{
By IAN MOORE \\ Staff Research Associate \\ Division of Biological Control \\ University of California, Riverside
}

The generic name $O$ phites was validated by Erichson ( 1839, p. 29) by inclusion in a key to the genera of the tribe Paederini. In the second half of the same work ( 1840, p. 627) Erichson described in detail the genus and three included species from Colombia. Sharp ( 1876) added a new species from Brazil and Lynch-Arribálzaga (1884) added anotiher from Argentina. In I90 I Fauvel described a sixth species from Colombia. In 1952 Blackwelder called attention to the fact the name Ophites was preoccupied by Wagler, 1830, and proposed the substitute name Opithes.

In I904 Fauvel described from Brazil two genera, Mimophites and Bolbophites, which closely resemble Opithes. Members of each of these genera have the slender neck and narrow pronotum of Opithes. Blackwelder in 1944 placed the former next to Ophites (=Opithes) and the latter far removed in the subtribe Echiasteres. Seevers (1965) reviewed Mimophites and Bolbophites. He stated "Mimophites appears to belong to Casey's (1905) subtribe Stilici, a group included in Blackwelder's (1944) Lathrobii." In Opithes the first antennal segment is as long as the next six combined, more than one-third of the length of the entire antenna; the gular sutures are narrowly but distinctly separate; the neck is about one-fourth the length of the head and the last segment the maxillary palpus is not subulate but is almost as wide at base as the apex of the third segment and is conical. Mimophites differs from Opithes in that the first antennal segment is short, no longer than the next two combined, and the antennae are not anteriorly flexile; the neck is short; the gular sutures are united and the last segment of the maxillary palpus is subulate and quite slender. Bolbophites differs from Opithes in that the first antennal segment is no longer than the next three together; the gular sutures are united and the last segment of the maxillary palpus is subulate.

*Manuscript received by the editor June 10, 1974. 
Bolbophites is placed in the subtribe Echiasteres because the prosternum is produced posteriorly and thence expanded laterally to the hypomera, a character which is usually concealed by the anterior coxae and consequently difficult to see. It is readily distinguished by the pronotum and elytra being provided with large, conspicuous knobby protrusions. Mimophites includes several species. Borgmeier (1949) reviewed the genus and provided a key to the species. Fauvel (1904) included two species in Bolbophites at the time he described the genus. No species have been added since.

Blackwelder (1939) included Ophites (= Opithes) in a key to the genera of the subfamily Paederinae where he indicated its close relationship to Homaeotarsus by the presence of geniculate, anteriorly flexile antennae. Specimens of Mimophites and Bolbophites apparently were not available to Blackwelder as he did not include them in his key.

In this work I describe a new species of $O$ pithes from Mexico and for the first time present a key to the species of the genus.

Nothing has been recorded concerning the habits of the various species nor of the habitats in which they are found. Unfortunately, Mr. Crandall cannot recall the circumstances under which he captured the specimen described here from Mexico.

\section{Key to the species of Opithes Blackwelder}

I. Head and pronotum ferrugineus. ......................................... 2

Head and pronotum black or piceus. .................................. 3

2. Surface of head anterior to eyes with two foveae, length $12 \mathrm{~mm}$.; Mexico. ............................................ crandalli new species Surface of head anterior to eyes with three foveae, length io mm.; Argentina. fauveli Lynch-Arribálzaga

3. Head and pronotum opaque. .......................................... 4

Head and pronotum shining.

4. Abdomen densely opaque; Brazil. .................... stilicoides Sharp Abdomen semi-shining; Columbia. ................. velitarsis Erichson

5. Tibiae in part pale. …………..................................... 6

Tibiae entirely black; Columbia. .................. versatilis Erichson

6. Elytra black; Columbia. ......................... raphidioides Erichson

Elytra aeneus; Columbia. .................................. bugnioni Fauvel

Opithes crandalli new species

Description of holotype.

Color. - Head, pronotum and first four and one-half abdominal 
segments bright ferrugineus with the head slightly darker. Elytra deep black with the humeri and base piceus and the apices narrowly flavate. Apical two-thirds of fifth tergite black. Antennae and mouth parts ferrugineus. Legs pale flavate with the apices of the femora and the bases of the tibiae piceus, tarsi ferrugineus. Beneath largely ferrugineus with the mesasternum and metasternum piceus, apical half of fifth and most of sixth sternites black, the narrow apex of the latter flavate.

Head. - Head three-fifths as wide as long, widest across the eyes, the posterior margins of which are a little less than half the distance from the apex to the base; subparallel in anterior half, thence, rapidly narrowed to a cylindrical neck which is about one-fifth the length and one-fourth the width of the head. Anterior margin of head straight. Supra-antennal ridge prominent. Eye prominent, onefifth the length of head. Antenna three-fifths longer than head, densely pubescent from the third segment, first segment as long as next six together, second segment twice as long as wide, narrower than apex of first, third through fifth segments each about two and one-half times as long as wide, about as wide as second, sixth through tenth segments each slightly shorter and just perceptibly wider than the preceding so that the tenth is only about one-fifth longer than wide, eleventh about as long as wide, pointed in apical third. Upper surface of head shining, with barely perceptible reticulate ground sculpture, finely, evenly, sparsely punctured throughout with a fine short pubescence interspersed with less numerous longer setae; at the base of each antennal ridge with a prominent fovea jetween which is a slight cntral impression, otherwise evenly convex. Each side of head behind the eyes with two large umbilicate punctures, the first on the upper surface one-third of the length of the eye from it, the other on the lower surface about the length of the eye from it. Under surface of the head impunctate except for about two dozen scattered fine punctures bearing fine long setae. Gular sutures widely separated in front, rapidly converging and thence very narrowly but distinctly separate to the neck where they diverge slightly. Maxillary palpus four-segmented, the first segment short, second long and slender, slightly arcuate, widest at apex, third slightly longer than second, hardly wider, widest at apex, almost straight, fourth segment semi-membranous, almost as wide at base as apex of third, almost as long as wide, conical with apex rather abruptly acuminate and membranous. Labial palpus three-segmented, first segment about twice as long as wide, second segment about as wide but half again as long as first, third segment about as long as first, acicular. Mandibles 


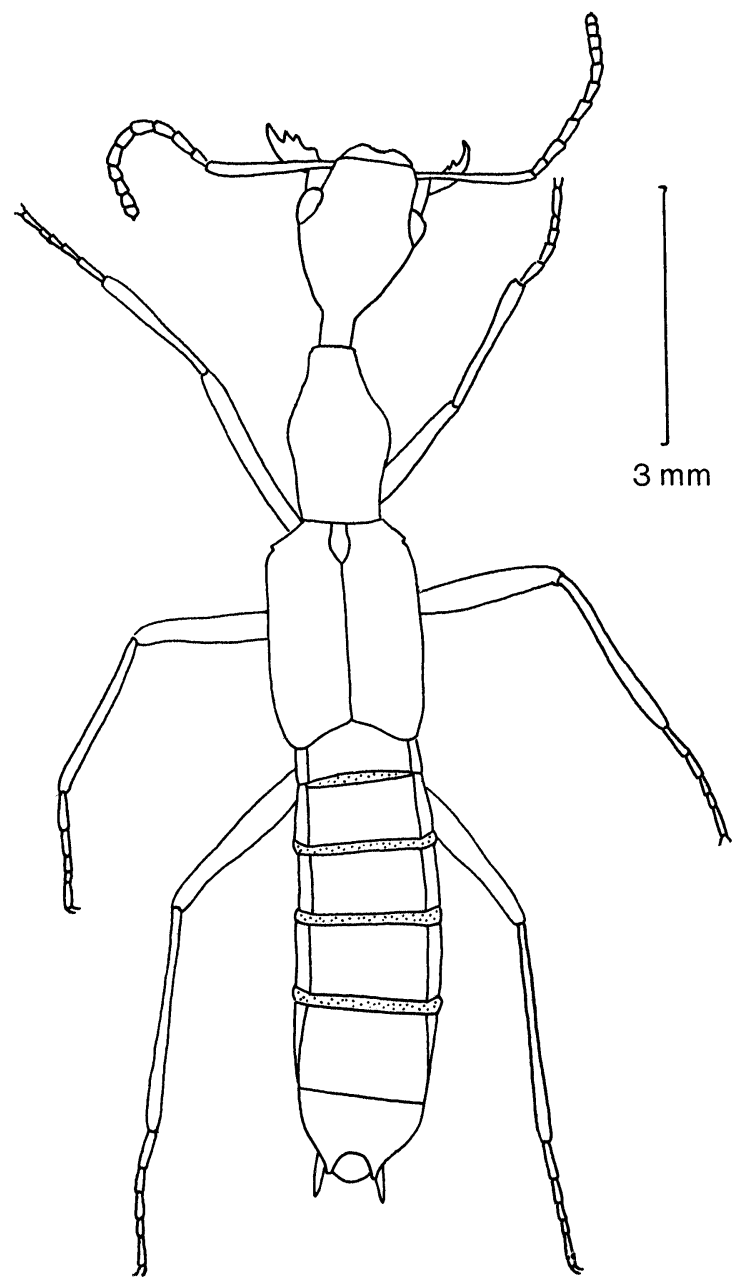

Figure 1. Opithes crandalli Moore, dorsal view. 
long, slender, falcate, each with two large internal teeth, those of the left of nearly equal size, those of the right with the proximal tooth smallest.

Thorax. - Pronotum four-fifths as long as head, a little less than half as wide as long, widest near the middle, rapidly constricted to the front where it is about twice as wide as neck, rounded at the middle and narrowed posteriorly for a short distance, then straight and nearly parallel to the narrowly rounded basal angles; base straight, about one-fifth narrower than widest point; surface evenly convex, highly polished, impunctate on disc with large scattered umbilicate punctures along the base and for a short distance forward along each side. Superior lateral line short, about half the length of the pronotum, evanescent at each end. Prosternum longitudinally carinate with a few fine scattered setae. Lateral prosternal carina obliterated. Mesosternum narrow, not produced between the coxae. Metasternum long, broad, with an impressed longitudinal central line, very finely, very sparsely pubescent. Elytra hardly wider than head, conjointly almost one and one-half times as long as wide, humerus obtusely angulate with a minute tooth at the angle, sides nearly straight and nearly parallel, outer apical angles rounded, apices oblique, inner apical angles obtuse, sutures elevated, disc with six or seven irregular rows of crowded coarse punctures, interspaces shining. Legs very long and slender, anterior tarsus not dilated, without dense spatulate setae beneath. First segment of posterior tarsus longer than last segment, segments two, three and four decreasing in length.

Abdomen. - Parallel, finely, sparsely, punctured, the punctures set with fine black setae with a few scattered larger setae particularly along the posterior margin. Last two segments somewhat more densely punctured than the others. Apical margin of sixth tergite about one-third of distance on each side produced in a large blunt tooth, the margin between the teeth broadly evenly arcuately emarginate. Vestiture beneath similar to above. Apex of sixth sternite arcuate with a very slight emargination in the central eight.

Length. - I $2 \mathrm{~mm}$.

Sex unknown but probably a female because of the condition of the sixth sternite, other species in the male have a deep incision in the apex of that sclerite.

Mexico, Sinaloa, Mazatlán, December I966, R. H. Crandall, Jr., collector.

Disposition of type. - California Academy of Sciences, San Francisco. 


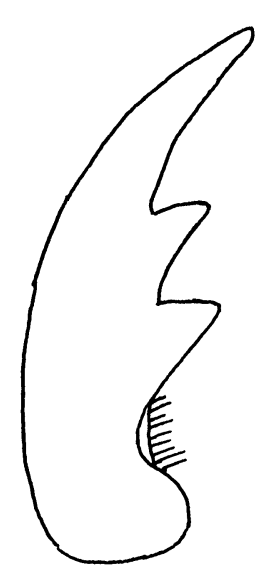

2

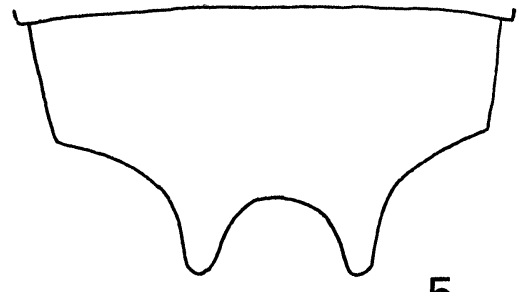

5
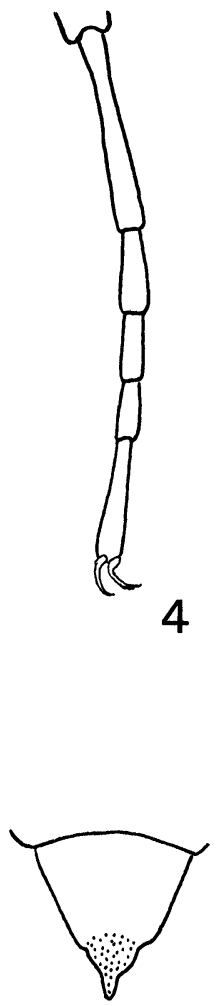

6

Figures 2-6. Opithes crandalli Moore. 2, left mandible; 3. right mandible; 4 , posterior tarsus; 5 , sixth tergite; 6 , fourth segment of maxillary palpus. 
Notes. - This species is very similar in color to fauveli LynchArribálzaga from Argentina but is without the central fovea on the disc of the head and has the abdomen more regularly marked without splotches of black.

This striking species is named for its collector, R. H. Crandall, Jr., who with his father has added many fine specimens to our collection.

\section{Literature Cited}

BLACKWELDER, R. E.

1939. A generic revision of the staphylinid beetles of the tribe Paederini. Proc. U. S. Nat. Mus. 87: 93-125.

1944. Checklist of the coleopterous insects of Mexico, Central America, The West Indies, and South America, part 1. U. S. Nat. Mus. Bull. 185 : 1-188.

1952. The generic names of the beetle family Staphylinidae with an essay on genotypy. U. S. Nat. Mus. Bull. 200: i-iv, 1-483.

BORGMEIER, T.

1949. Neue Gatungen und Arten termitophiler Staphyliniden aus Brazilien, nebst einem Katalog aller bischer aus der neotropischen Region beschriebenen Arten (Col. Staph.). Revista Ent., 21: 625-676, illus.

Erichson, W. F.

1839. Genera et species staphylinorum coleopterorum familaea. (part 1), pp. 1-400. Berlin.

1840. Genera et species staphylinorum coleopterorum familaea. (part 2), pp. 401-954. Berlin.

Fauver, C. A.

1901. Voyage de M. de Dr. Ed. Gugnion au Venezuela, en Colombie et aux Antilles. Staphylinides. Revue d'Entomologie, 20: 251-252.

1904. Staphylinides myrmecóphiles du Brésil Revue d'Entomologie, 32: 276-283, illus.

LYNCH-ARribÁLZAGA, F.

1884. Los Estafilinos de Buenos Aires. Bol. Acad. Nat. Sci. Cordova, 7: 5-392.

SeEvers, C. $\mathrm{H}$.

1965. The systematics, evolution and zoogeography of staphilinid beetles associated with army ants (Coleoptera: Staphylinidae).

SHARP, D. Fieldiana: Zoology 47: 138-351, figs. 14-37.

1876. Contributions to an insect fauna of the Amazon Valley. Trans. Ent. Soc. London, 1876: 27-424. 

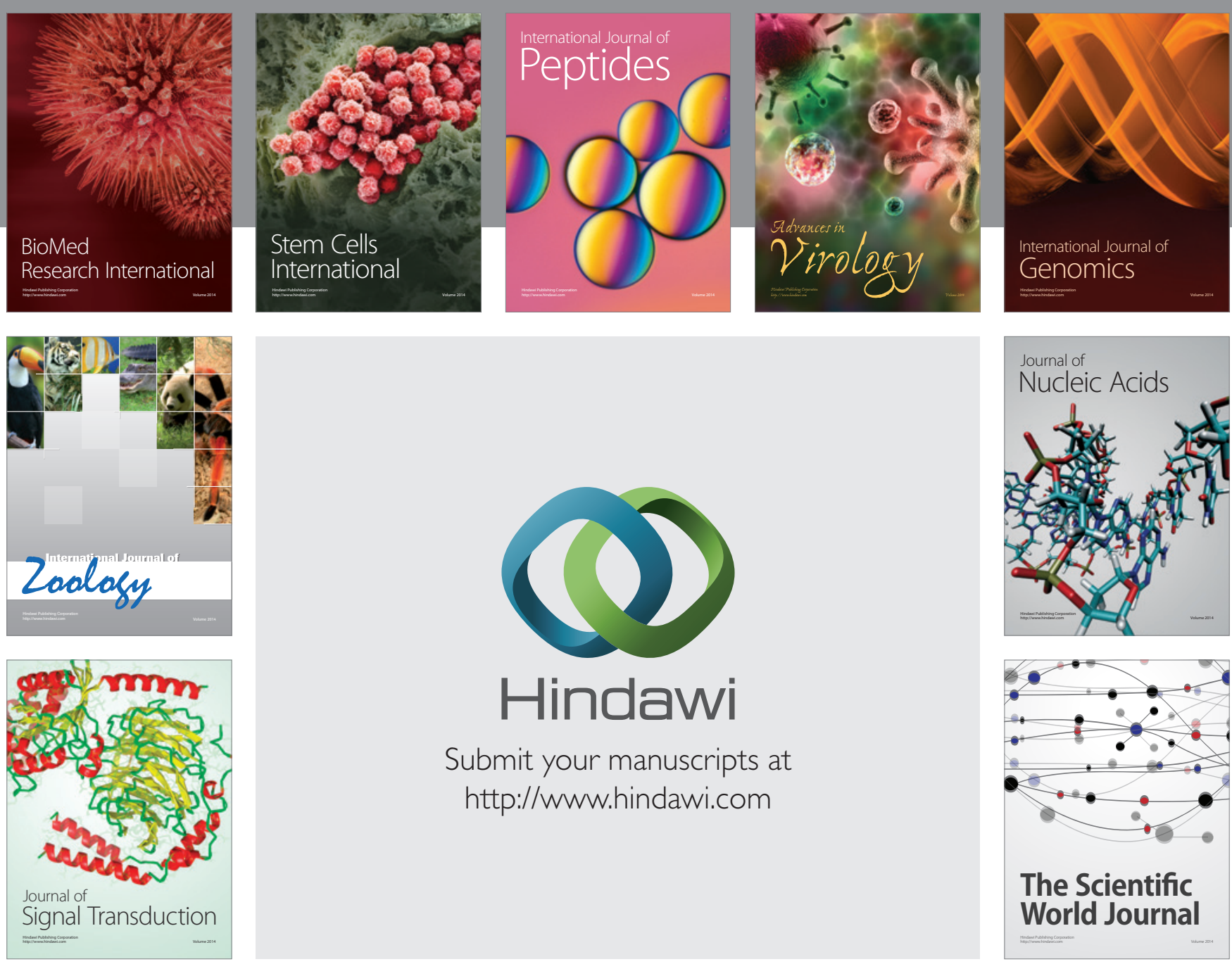

Submit your manuscripts at

http://www.hindawi.com
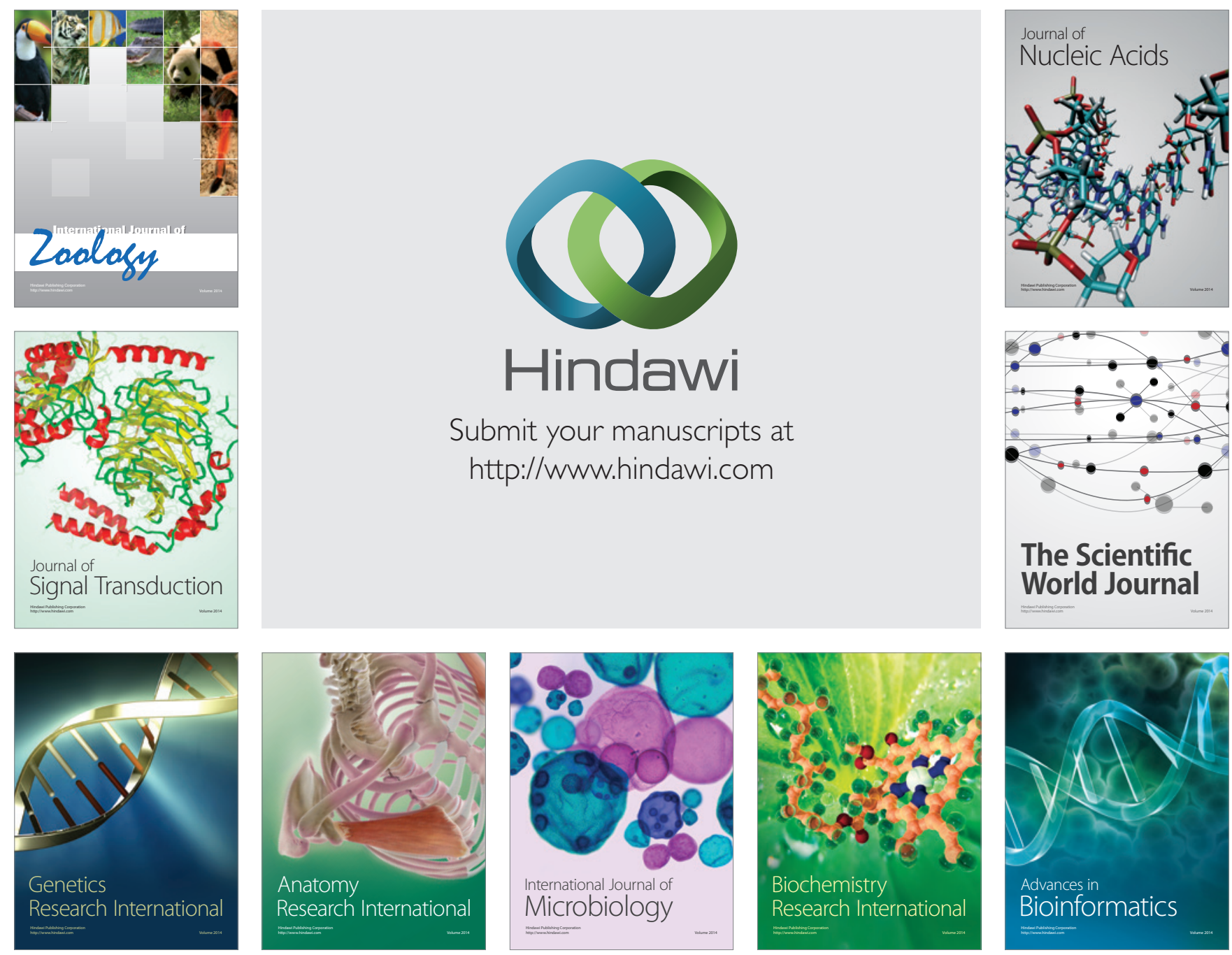

The Scientific World Journal
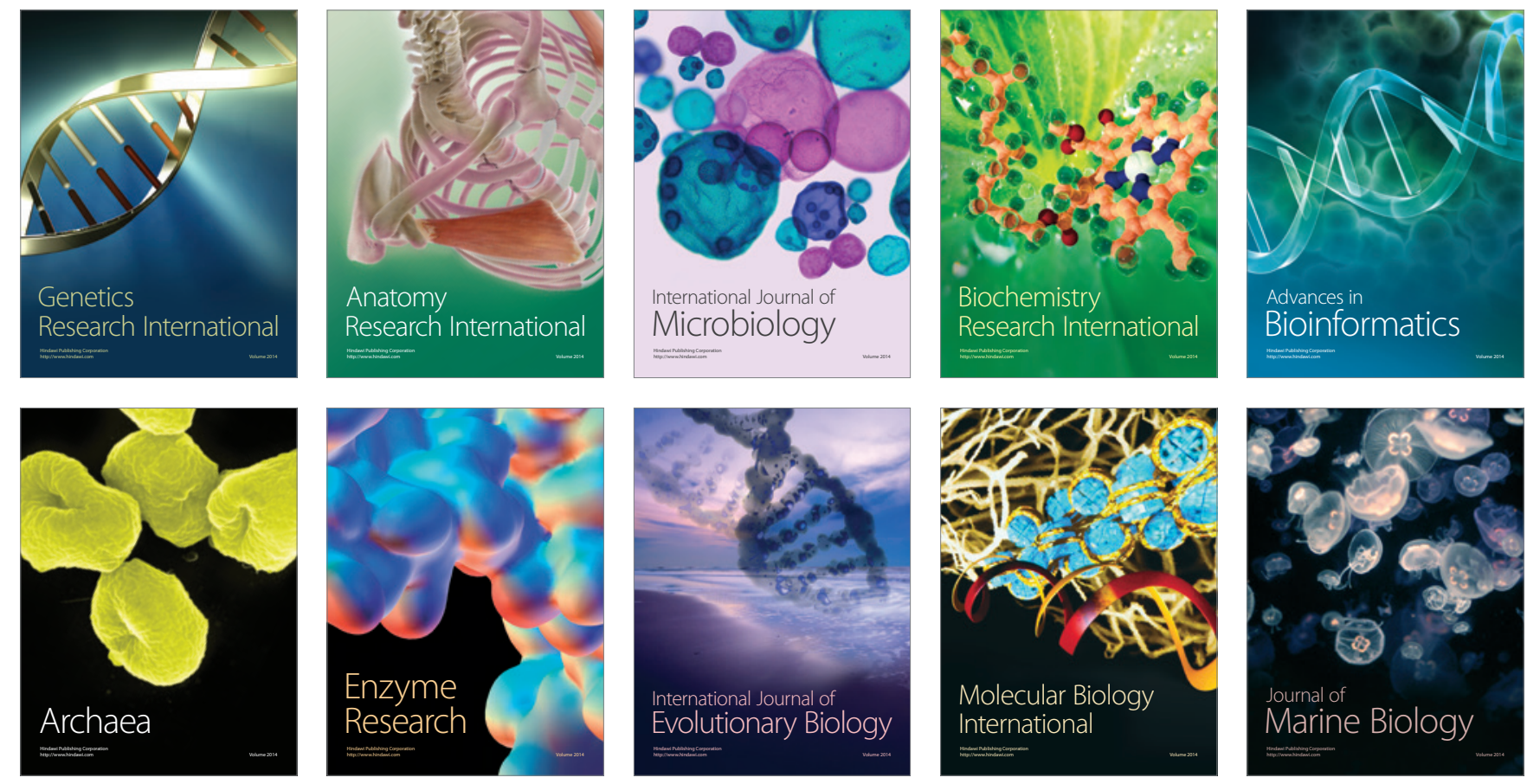